\title{
Effect of Glucans from Caripia montagnei Mushroom on TNBS-Induced Colitis
}

\author{
Marilia da S. Nascimento Santos ${ }^{1}$, Joedyson Emmanuel de M. Magalhães ${ }^{1}$, \\ Luiza Sheyla Evenni P. Will Castro ${ }^{1}$, Thuane de Sousa Pinheiro ${ }^{1}$, Diego Araujo Sabry ${ }^{2}$, \\ Leonardo Thiago Duarte B. Nobre ${ }^{1}$, João Paulo Matos Santos Lima ${ }^{1}$, Iuri Goulart Baseia ${ }^{3}$ and \\ Edda Lisboa Leite ${ }^{1, *}$
}

1 Laboratory of Glycobiology, Department of Biochemistry, Federal University of Rio Grande do Norte, Av. Salgado Filho, 3000, Bairro L. Nova, CEP 59078-970, Natal, RN, Brazil;

E-Mails: mariliabio84@gmail.com (M.S.N.S.); joedyson_magalhaes@hotmail.com (J.E.M.M.); 1sepwill_@gmail.com (L.S.E.P.W.C.); tutu_sousa@hotmail.com (T.S.P.); leo.dnobre@gmail.com (L.T.D.B.N.); jplslima@gmail.com (J.P.M.S.L.)

2 Department of Biochemistry, Federal University of Paraná, UFPR, Curitiba CEP 81531-980, PR, Brazil; E-Mail: popoh_diego@hotmail.com

3 Laboratory of Mycology, Department of Botany, Zoology and Ecology, Federal University of Rio Grande do Norte, Av. Salgado Filho, 3000, Bairro L. Nova 59078-970, Natal, RN, Brazil; E-Mail: baseia@cb.ufrn.br

* Author to whom correspondence should be addressed; E-Mail: eddaleite@cb.ufrn.br; Tel.: +55-084-3215-3416; Fax: +55-084-3215-3415.

Received: 18 November 2013; in revised form: 13 January 2014 / Accepted: 19 January 2014 / Published: 10 February 2014

\begin{abstract}
In this study, we evaluated the effect of different doses of polysaccharides extracted from Caripia montagnei mushroom at different intervals of treatment on colonic injury in the model of colitis induced by 2,4,6-trinitrobenzene sulfonic acid (TNBS). The FT-IR analysis and NMR showed that the polysaccharides from this species of mushroom are composed of $\alpha$ - and $\beta$-glucans. The colonic damage was evaluated by macroscopic, histological, biochemical and immunologic analyses. The results showed the reduction of colonic lesions in all groups treated with the glucans. Such glucans significantly reduced the levels of IL-6 (50 and $75 \mathrm{mg} / \mathrm{kg}, p<0.05$ ), a major inflammatory cytokine. Biochemical analyses showed that the glucans from $C$. montagnei acted on reducing levels of alkaline phosphatase $(75 \mathrm{mg} / \mathrm{kg}, p<0.01)$ and myeloperoxidase $(p<0.001)$, a result confirmed by the reduction of cellular infiltration observed microscopically. The increase
\end{abstract}


of catalase activity possibly indicates a protective effect of these glucans on colonic tissue, confirming their anti-inflammatory potential.

Keywords: colitis; polysaccharides; mushroom; anti-inflammatory; Caripia montagnei

\section{Introduction}

Ulcerative colitis, which together with Crohn's disease includes inflammatory bowel diseases (IBDs), consists of an idiopathic inflammatory process involving the mucosa of the colon and rectum, whose incidence varies between populations $[1,2]$.

The pathogenesis of chronic intestinal inflammation results from an intestinal mucosa dysfunction resulting from the overproduction of pro-inflammatory mediators that trigger the immune system alterations. Allied to this is the suggestion that the union of genetic factors confers disease susceptibility to environmental factors [3].

Clinical manifestations are characterized by changes in gastric motility, weight loss, ulceration of the colon mucosa, fever, shortening of the colon and diarrhea with blood and/or mucus [4].

Current treatments include commonly used drugs, such as aminosalicylates, which assist in maintaining remission of crises, corticosteroids, which are utilized during acute episodes, and immunomodulators [5]. However, these treatments are often associated with severe side effects and high costs [6,7]. Thus, there is a search for safe natural compounds that can contribute to the prevention or even treatment of inflammatory diseases [8-11].

Initial studies with the aqueous extract of Caripia montagnei mushroom found its anti-inflammatory potential. In this study, the polysaccharidic extract was able to not only reduce inflammatory edema and reduce levels of leukocyte migration, but also significantly reduce the levels of cytokines and nitric oxide [10]. The aim of this study was to evaluate the action of glucans from the Caripia montagnei model on 2,4,6-trinitrobenzene sulfonic acid (TNBS)-induced colitis in rats and their effects on interleukin levels (IL-1 IL-6), catalase, myeloperoxidase (MPO) enzymes and nitric oxide. Moreover, assessment of their action in colonic tissue was performed by histological analysis.

\section{Results}

\subsection{Chemical Analysis}

We previously reported that the aqueous extract rich in polysaccharides of the fruiting bodies of Caripia montagnei showed anti-inflammatory potential using the models, carrageenan-induced plantar edema and peritonitis induced by thioglycollate. There was a reduction in inflammatory edema and in the levels of leukocyte migration, lowering the levels of nitric oxide and cytokines, in addition to inhibiting expression of nuclear factor $\kappa \mathrm{B}$ peritoneal lavage from mice [10]. The aqueous extraction of polysaccharides is a technique widely used in scientific studies [12-14]. Its efficiency in obtaining polysaccharides, high yield and low expense may be the main reasons for their large employment.

The measurements revealed that the compound extracted from the mushroom, Caripia montagnei, is composed mainly of polysaccharides (96\%), had a low protein content $(2.5 \%)$ and phenolic 
compounds $(1.5 \%)$. The monosaccharide composition showed the glucose as sugar predominantly existing in the obtained polysaccharide fraction of C. montagnei [10].

\subsection{FT-IR Spectrum}

The FT-IR analysis (Figure 1) revealed the broadband centered around $3500 \mathrm{~cm}^{-1}$, which is a characteristic sign of the band of axial stretching of $\mathrm{OH}$. The existing signal in the range of 2900 and $2800 \mathrm{~cm}^{-1}$ means the presence of aldehyde grouping $(\mathrm{CH})$ in axial strain. The analysis also revealed absorptions around $1300-1800 \mathrm{~cm}^{-1}$, which are characteristic of the presence of carbohydrates $[15,16]$. Moreover, the analysis revealed the presence of the band between 1000 and $1100 \mathrm{~cm}^{-1}$, i.e., $1045 \mathrm{~cm}^{-1}$ being characteristic of the presence of $\beta$-glucans due to $O$-substituted glucose residues [17,18]. A signal was found in the range of $855 \mathrm{~cm}^{-1}$, which corresponds to the presence of $\alpha$-glucans [19].

Figure 1. FT-IR spectra of the polysaccharides obtained by aqueous extraction followed by ethanol precipitation of the Caripia montagnei mushroom.

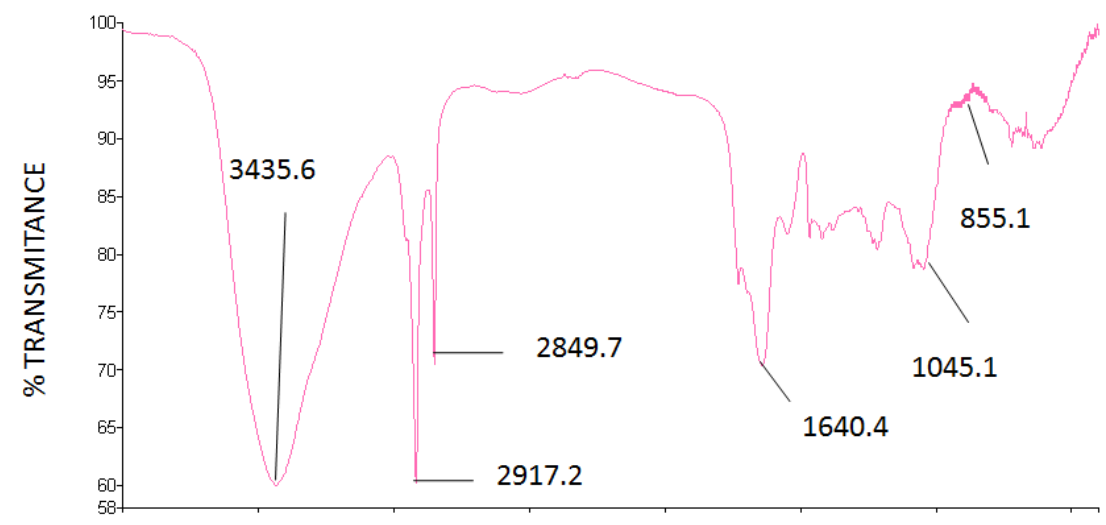

WAVENUMBER $\left(\mathrm{cm}^{-1}\right)$

\subsection{NMR}

The ${ }^{1} \mathrm{H}$ spectrum of polysaccharides from $C$. montagnei showed the anomeric signals in the region 4-5 ppm (Figure 2A). The signs existing in 5.07 and $5.9 \mathrm{ppm}$ are attributed to the presence of $\alpha$-glucans. Signs existing in 4.96 and $4.98 \mathrm{ppm}$ correspond to the presence of $\beta$-glucans [20], corroborating the results found in the analysis of FT-IR. The main anomeric signals $(\mathrm{C}-1 / \mathrm{H}-1)$ in the "heteronuclear single quantum correlation spectroscopy" (HSQC) (Figure 2B) were up and 100.55/5.01, 103.32/5.01 and 103.99/4.97, corresponding to the C-1 units A, B and C, respectively, in accordance with the decrease in anomeric chemical shifts [21]. The signals at low resonance frequency in C-1 to 100.32 and 103.55 and at high frequency in H-1 at 5.01 indicate the presence of $\rightarrow \alpha-\mathrm{D}-\mathrm{glc} \rightarrow$ [22-24], while the signal at 103.99/4.97 indicates the presence of terminal Glc ( $\beta$-Glc H-1 to 4.97 ppm). 
Figure 2. Chemical characterization of the polysaccharides of Caripia montagnei. (A) NMR spectrum of ${ }^{1} \mathrm{H}$; (B) HSQC spectrum solution in $\mathrm{D}_{2} \mathrm{O}$.
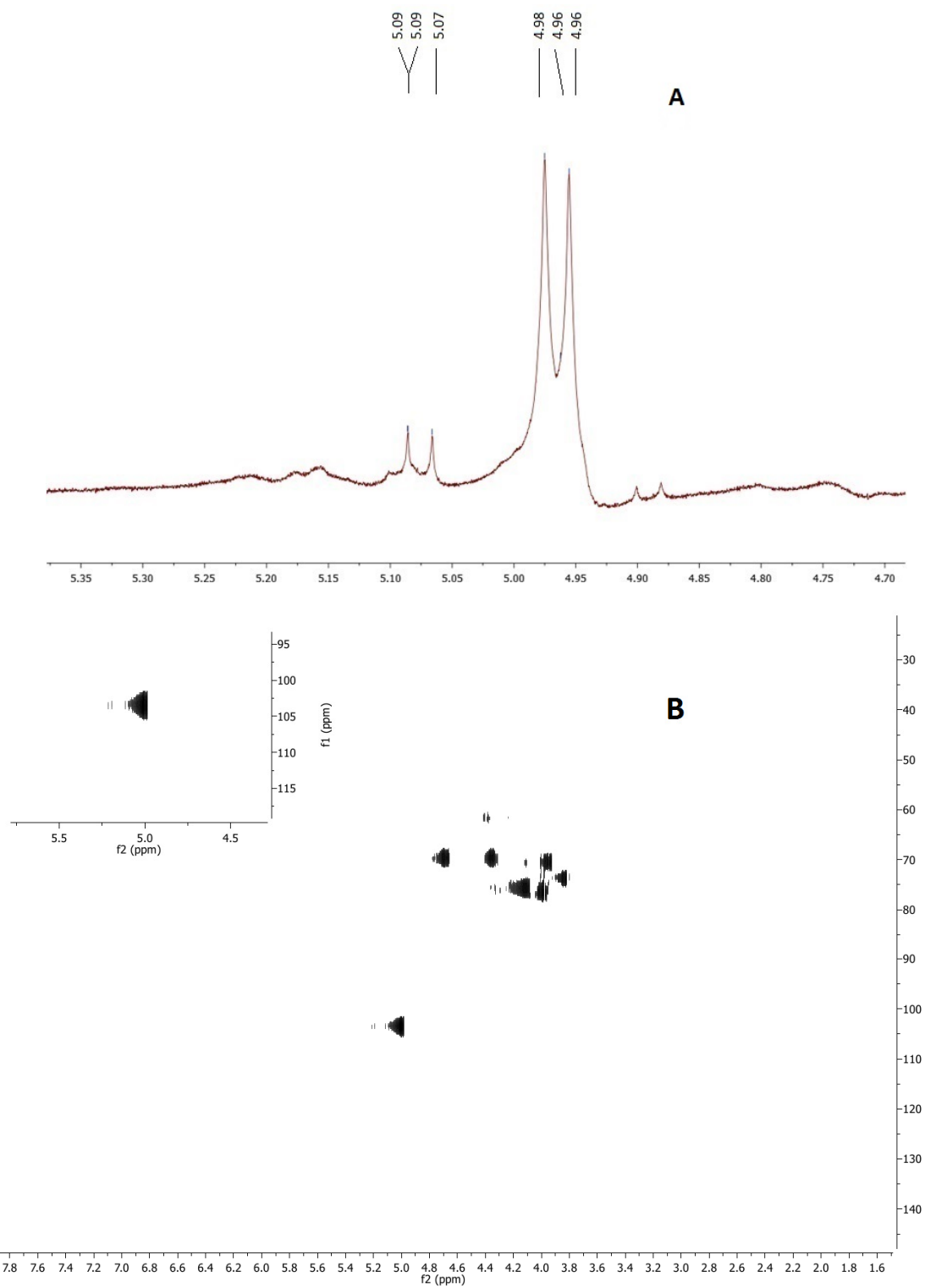

\subsection{Macroscopic Analysis}

Trinitrobenzene sulfonic acid (TNBS) and dextran sulfate sodium (DSS) or oxazolone are typically used in models of inflammatory bowel disease (IBD) chemically-induced inflammation, due to the immediate, high reproducibility and simplicity of the induction process [25].

Glucans extracted from Caripia montagnei mushroom were used to evaluate their anti-inflammatory potential that is well described in a model of colitis induced by TNBS. After the induction of colitis, the presence of colonic lesions, such as hyperemia and ulcerations, was observed. As can be seen in Figure 3, the intracolonic administration of TNBS promoted a considerable increase of macroscopic lesions. In the positive control group were commonly found lesions, such as ulcers and necrosis (Figure 3A), in contrast to the negative control group in which there were no injuries (Figure 3B). Treatment of animals with dexamethasone (Figure 3I,J) and glucans from C. montagnei at different intervals and doses was able to reduce the damage observed (Figure $3 \mathrm{C}-\mathrm{H}$ ). 
Macroscopic analyses were evaluated for the intestinal damage represented in Figure $3 \mathrm{~A}-\mathrm{H}$ by assigning a score and showed the extent and severity of intestinal damage. In this analysis, the score, which shows the severity of intestinal damage, indicated that the untreated group, the positive control, presented a high score $(13.6 \pm 0.51)$, showing that the animal's intestinal injury induced colonic inflammation (Figure 3K). A significant reduction could also be seen between the positive control group and the group treated with dexamethasone $(0.5 \pm 0.54$ for both time intervals $)$ and the groups treated with glucan to $75 \mathrm{mg} / \mathrm{kg}$ at $12 \mathrm{~h}$ intervals $(6.6 \pm 0.81)$ and $24 \mathrm{~h}(6.5 \pm 0.83)$.

Figure 3. Macroscopic colonic lesions of rats $(n=3)$ with 2,4,6-trinitrobenzene sulfonic acid (TNBS)-induced colitis. (A) Untreated animals: positive control; (B) a negative control; (C,D) treated every 12 and $24 \mathrm{~h}$, respectively, with $25 \mathrm{mg} / \mathrm{kg}$ of glucans of Caripia montagnei; (E,F) treated at intervals of 12 and $24 \mathrm{~h}$, respectively, with $50 \mathrm{mg} / \mathrm{kg}$ of glucans of C. montagnei; $(\mathbf{G}, \mathbf{H})$ treated every 12 and $24 \mathrm{~h}$, respectively, with $75 \mathrm{mg} / \mathrm{kg}$ of glucans of $C$. montagnei; $(\mathbf{I}, \mathbf{J})$ treated every 12 and $24 \mathrm{~h}$, respectively, with $100 \mathrm{mg} / \mathrm{kg}$ dexamethasone; $(\mathbf{K})$ the effect of glucans of Caripia montagnei in colonic inflammation. Data are expressed as the mean \pm standard deviation. $* * * p<0.001$.
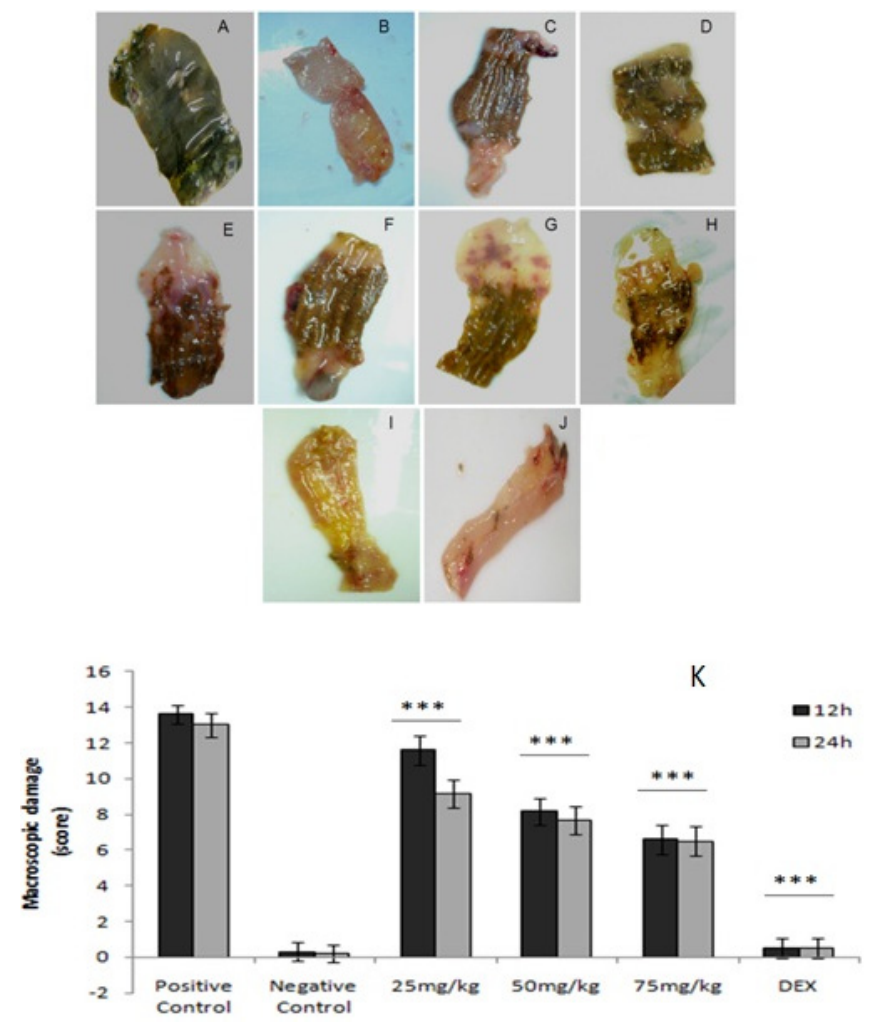

\subsection{Activity of Myeloperoxidase (MPO)}

Among the biochemical parameters studied here, the changes in the myeloperoxidase (MPO), alkaline phosphatase (ALP) and catalase (CAT) activities are highlighted.

MPO is an enzyme found in the azurophilic granules of neutrophils, and therefore, their quantification is related to the presence of these cells in different tissues, including the gastrointestinal tract. It was suggested that the influx of neutrophils at active sites of inflammation governs the process of various inflammatory diseases [26]. Activated neutrophils produce reactive species of oxygen and 
nitrogen in the intestinal mucosa, inducing oxidative stress, which plays a significant role in the pathogenesis of inflammatory bowel disease [27,28].

The activity of the enzyme, myeloperoxidase (MPO), was evaluated as a parameter to check the anti-inflammatory activity of the glucans of $C$. montagnei. Figure 4A shows that the administration of TNBS increased the MPO activity by more than six times when compared to the negative control. The results also showed that the treatments performed at different intervals $(24 / 24 \mathrm{~h}, 12 / 12 \mathrm{~h})$ with varying doses of glucans of $C$. montagnei were able to reduce the enzymatic activity significantly. The dose of $75 \mathrm{mg} / \mathrm{kg}$ glucans reduced the MPO activity by about 3.7 and 3.8 times $(p<0.001)$ when administered every 12 and $24 \mathrm{~h}$, respectively. The reduction in enzyme activity was dose-dependent, and different ranges of treatments showed no statistically significantly interference in the activity of the glucans of $C$. montagnei.

Figure 4. Evaluation of the influence of the glucans from Caripia montagnei on enzyme activity. (A) Myeloperoxidase and (B) alkaline phosphatase in colonic tissue $(n=4)$ with TNBS-induced colitis. Data were expressed as the mean \pm standard deviation. ${ }^{*} p<0.05$; ** $p<0.01 ; * * *<<0.001$.

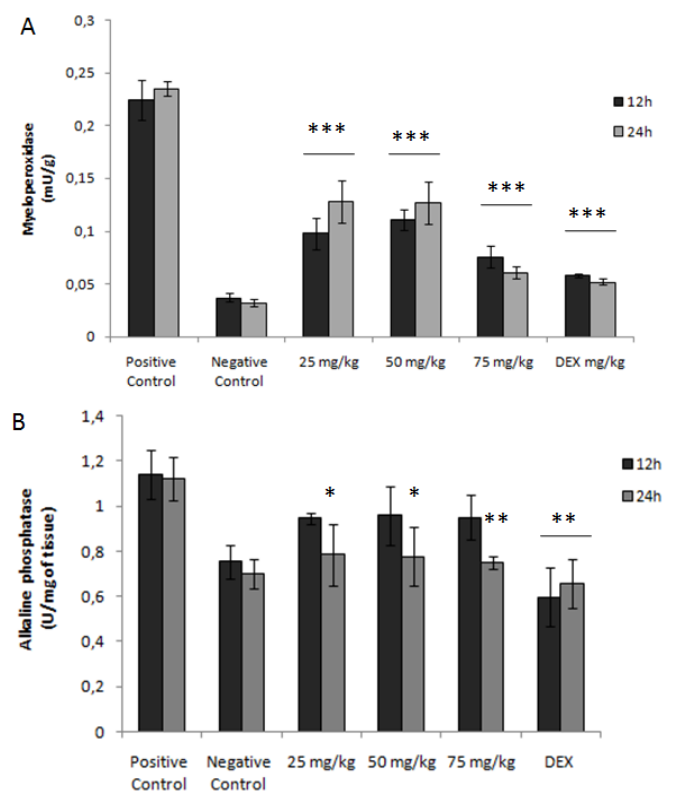

\subsection{Activity of Alkaline Phosphatase}

The activity of the enzyme, alkaline phosphatase (AP), was another colonic biochemical parameter analyzed, and several studies demonstrate the upregulation of alkaline phosphatase and the mechanisms involved in experimental colitis [29]. High levels $(1.14 \pm 0.011$ and $1.21 \pm 0.097 \mathrm{U} / \mathrm{mg}$ for the groups treated every 12 and $24 \mathrm{~h}$, respectively) of AP were found in groups with TNBS-induced colitis (Figure 4B). However, the reason for the increased colonic AP found in ulcerative colitis is unknown, and it was previously reported that AP is a sensitive and safe marker of experimental colitis in mice [29]. The activity of the colonic enzyme, alkaline phosphatase (AP), was significantly reduced in the groups treated with $50 \mathrm{mg} / \mathrm{kg}(0.77 \pm 0.13 \mathrm{U} / \mathrm{mg} ; p<0.05)$ and $75 \mathrm{mg} / \mathrm{kg}(0.75 \pm 0.028 \mathrm{U} / \mathrm{mg}$; $p<0.01)$ glucans from $C$. montagnei at intervals of $24 \mathrm{~h}$. The observed effect was dose-dependent, and a reduction of up to $33 \% \pm 2.5 \%$ in the activity of AP was observed. 


\subsection{Nitric Oxide}

The increased generation of free radicals was also considered as having a key role in the pathogenesis of IBD [30,31]. During inflammation, monocytes are being recruited into the parenchyma tissue, which are activated to make cells with a phagocytic function [32]. These cells release cytokines, free radicals and nitric oxide, which can mediate tissue injury related to the inflammatory response [33,34].

Nitric oxide in most body fluids is rapidly metabolized to stable products, such as nitrite and nitrate. According to the results obtained (Figure 5A), the glucans from $C$. montagnei showed a high reduction $(p<0.001)$ of $\mathrm{NO}_{2} / \mathrm{NO}_{3}$ content in all the groups $(n=4)$ treated with the glucans at intervals of 12 and $24 \mathrm{~h}$. In inflammatory reactions, NO-derived cells stimulated by the action of cytokines are involved with changes in the vascular permeability of the inflamed tissue [35]. Thus, it is possible that the reduction of inflammatory mediator NO relates to the anti-inflammatory potential of the polysaccharides of Caripia montagnei.

Figure 5. (A) The effect of different doses of the glucans from Caripia montagnei in NO content in colonic tissue and $(\mathbf{B})$ catalase in colonic inflammation in the model of TNBS-induced colitis. Data were expressed as the mean \pm standard deviation. ${ }^{*} p<0.05$; ** $p<0.01 ; * * * p<0.001$ was considered statistically significant.

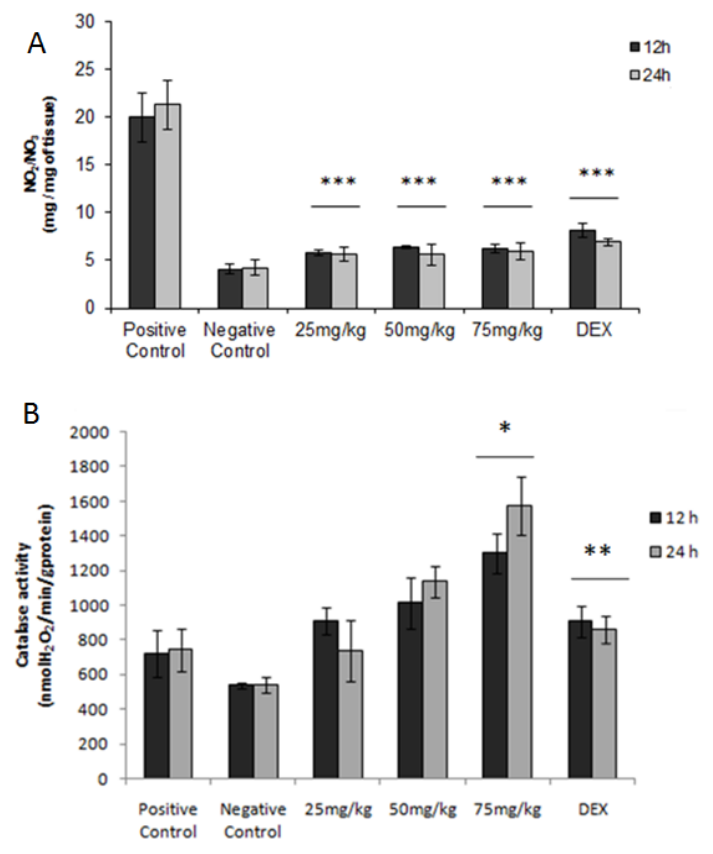

\subsection{Activity of Catalase}

The increased production of free radicals and a low concentration of endogenous antioxidant defense are related to damage to the intestinal mucosa in inflammatory bowel diseases [36]. Oxidative stress is considered a potential etiological factor for Crohn's disease [37]. Then, the antioxidant system is usually used to evaluate the protective effect of various compounds in colonic inflammation. The levels of catalase in the colonic region of the group of animals $(n=4)$ that did not receive TNBS were $537.23 \pm 17.05 \mathrm{nmol} \mathrm{H}_{2} \mathrm{O}_{2} / \mathrm{min} / \mathrm{g}$ protein. The administration of TNBS increased the levels of CAT to 
$723.52 \pm 137 \mathrm{nmol} \mathrm{H}_{2} \mathrm{O}_{2} / \mathrm{min} / \mathrm{g}$ protein. In all groups treated with the glucans from C. montagnei, a moderate increase was observed in CAT levels in a dose-dependent manner up to $1300.61 \pm 151$ $(p<0.05)$ and $1577.28 \pm 170(p<0.05)$ in the groups treated with $75 \mathrm{mg} / \mathrm{kg}$ at intervals of 12 and $24 \mathrm{~h}$, respectively (Figure 5B).

\subsection{Cytokine Analysis}

The effects of the derivatives of mushrooms include mitogenesis and activation of immune cells, such as hematopoietic cells, lymphocytes, macrophages and NK cells, resulting in cytokine production [38]. The environmental changes observed in colonic intestinal inflammation are usually associated with atypical immune responses of T-cells, which often lead to changing levels of cytokines. Glucans from Caripia montagnei were not able to alter the levels of IL-1 in all groups tested (Figure 6A). However, also verified was the effect of the glucans from C. montagnei on the release of IL-6-treated groups at different intervals and in a dose-dependent decrease, even reaching $64.8 \% \pm 4.11 \%$ and $57.2 \% \pm 6.45 \%$ of the cytokine levels in the colonic tissue of the group treated with $75 \mathrm{mg} / \mathrm{kg}$ glucan in intervals of 12 and $24 \mathrm{~h}$, respectively (Figure 6B). Among the substances most commonly used in the treatment of inflammatory bowel disease is tocilizumab, which operates on the inhibition of IL-6 [39]. Thus, glucans from C. montagnei also showed potential to reduce the levels of this cytokine and nitric oxide in colonic tissue.

Figure 6. The effect of glucans from Caripia montagnei in modulating the release of cytokines (A) IL-1 and (B) IL-6 in colonic tissue $(n=4)$ with inflammation induced by TNBS. Data were expressed as the mean \pm standard deviation. $* p<0.05 ; * * p<0.01$.
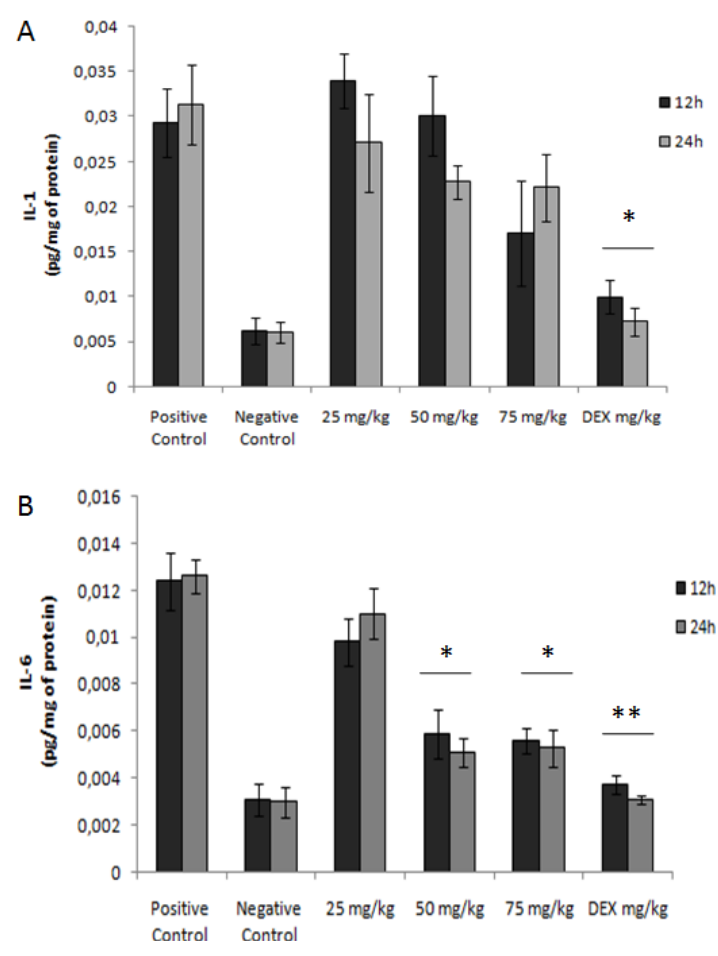


\subsection{Histological Analyses}

The high neutrophil infiltration is a consequence very characteristic of this experimental model of acute inflammation. Histologic examination revealed the destruction of the mucosal layer with prominent infiltration of inflammatory cells in the submucosa (Figure 7A). The negative control group showed no morphological tissue changes (Figure 7B). The treatment with dexamethasone (Figure 7I,J) and the glucans from $C$. montagnei at different intervals of time and dosage (Figure 7C-H) were able to reduce infiltration, corroborated with the observed reduction in the activity of the myeloperoxidase enzyme. The levels of tissue MPO activity are used as a quantitative measure for the infiltration of neutrophils in the inflammatory response in both clinical and experimental studies [40]. In this study, histological analyses confirm the reduction of MPO levels in groups treated with polysaccharides of $C$. montagnei, which can be viewed as reducing the cellular infiltration in the inflamed tissue.

Figure 7. Histological analysis of colon of different groups of animals with TNBS-induced colitis. (A) untreated animals: positive control; (B) a negative control; (C,D) treated every 12 and $24 \mathrm{~h}$, respectively, with $25 \mathrm{mg} / \mathrm{kg}$ of glucans of Caripia montagnei; (E,F) treated at intervals of 12 and $24 \mathrm{~h}$, respectively, with $50 \mathrm{mg} / \mathrm{kg}$ glucans of C. montagnei; $(\mathbf{G}, \mathbf{H})$ treated every 12 and $24 \mathrm{~h}$, respectively, with $75 \mathrm{mg} / \mathrm{kg}$ of glucans of C. montagnei; $(\mathbf{I}, \mathbf{J})$ treated every 12 and $24 \mathrm{~h}$, respectively, with $100 \mathrm{mg} / \mathrm{kg}$ of dexamethasone. The figures with arrows indicate destruction of the mucosal layer with infiltration of inflammatory cells.

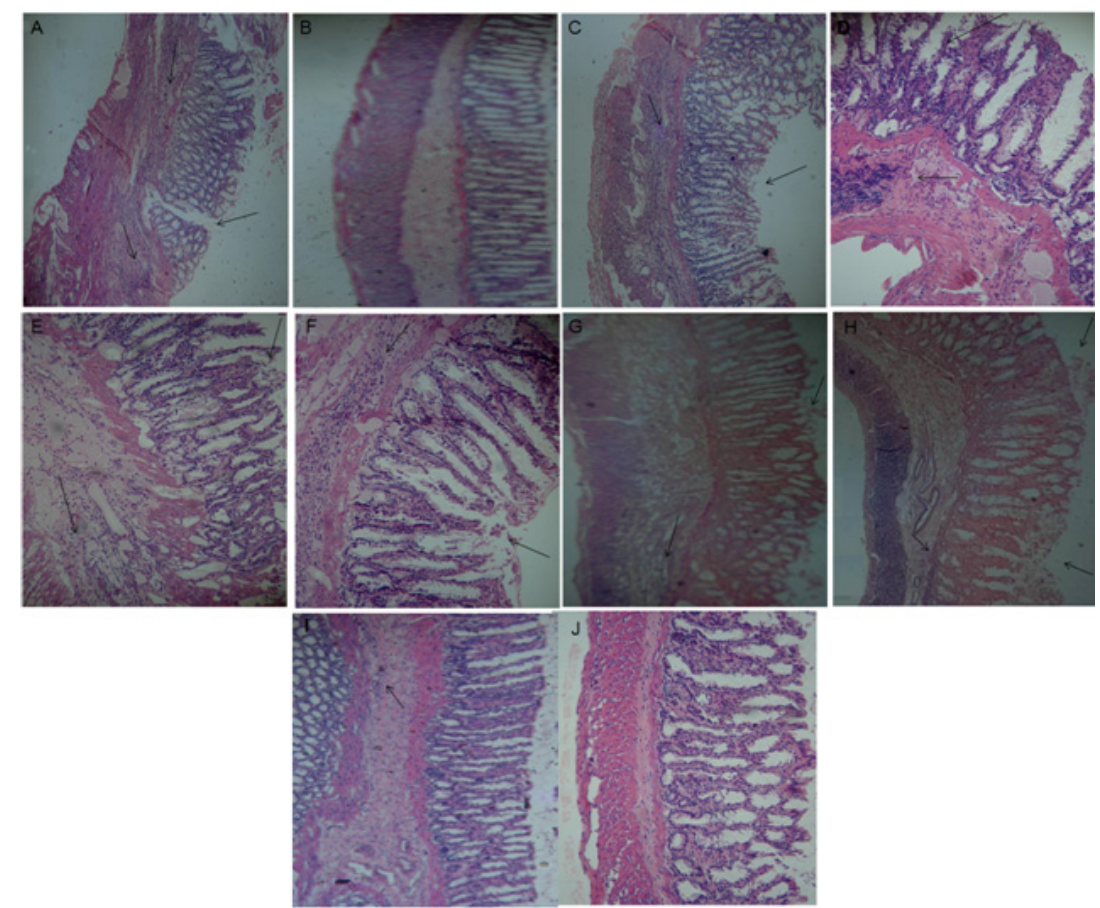

\section{Discussion}

Mushrooms appear to be a good source of natural products [41,42], especially anti-inflammatory ones $[43,44]$. Aqueous extracts from mushrooms have long been used in oriental medicine as natural 
drugs. In addition, several studies have demonstrated the pharmacological potential of these extracts [45-47]. Fungal polysaccharides have severe effects on a variety of leukocytes, including macrophages, neutrophils, eosinophils and NK cells, as well as non-immune cells, such as endothelial cells, alveolar epithelial cells and fibroblasts [48-50].

Inflammatory bowel disease is complex, involving a wide range of molecules, including cytokines. Recent investigations support the important role of interleukin-6 (IL-6) in inflammatory bowel disease, showing that these cytokine levels are increased in patients with this inflammatory process [51]. $\mathrm{NF}-\kappa \mathrm{B}$ is a transcriptional factor that regulates the synthesis of cytokines (TNF- $\alpha$, IL-1 $\beta$, IL-6 and IL-8). In addition, it can stimulate iNOS, increasing the production of NO [52-54]. Mushrooms have been shown to possess anti-inflammatory activity via the suppression of the expression of interleukins and NO [55,56]. Previous studies with extracts of $C$. montagnei showed that these polysaccharides were able to reduce inflammation in a model of acute peritonitis reducing the expression of $\mathrm{NF}-\kappa \mathrm{B}[10]$. In the present study, Caripia montagnei was shown to reduce the levels of important mediators, such as the cytokines, IL-6 and NO. In inflammatory reactions, NO-derived cells stimulated by the action of cytokines are involved with changes in the vascular permeability of the inflamed tissue. The decreased levels of NO were reported to be a key factor in reducing inflammation. The anti-inflammatory activity of the mushroom, I. obliquus, was attributed to the inhibition of the production of this inflammatory mediator [57]. In the model of colitis induced by TNBS, polysaccharides of $C$. montagnei showed reduced levels of IL-6 and NO, as well as others important markers, such as myeloperoxidase. Catalase (CAT) is an important cellular antioxidant. CAT is able to degrade hydrogen peroxide to form water. The protective effect of $C$. montagnei verified by increased levels of catalase may be associated with the reduced generation of reactive oxygen species. Thus, the anti-inflammatory activity displayed by these polysaccharides can be attributed to the inhibition of these important inflammatory mediators.

\section{Experimental Section}

\subsection{Mushrooms}

The mushrooms were collected in areas of the Atlantic Forest in the city of Natal (Rio Grande do Norte, Brazil), and after collection, the fungi were identified by Prof. Dr. Iuri Goulart Baseia, PhD in the Department of Zoology, Botany and Ecology, UFRN. The species were deposited in the herbarium at UFRN (UFRN fungi-836).

\subsection{Animals}

The studies were conducted with male Wistar rats (150-200 g) kept in a vivarium of the Department of Biochemistry, UFRN. All animals used in the testing were subjected to food and water ad libitum in controlled light conditions (12 h light/dark) and a temperature constant at $23 \pm 2{ }^{\circ} \mathrm{C}$. The animals were acclimatized in the laboratory for at least $4 \mathrm{~h}$ before the experiments and were used only once. The tests were approved $\left(\mathrm{n}^{\circ} 014 / 2010\right)$ by the Ethics Committee of the Federal University of Rio Grande do Norte (UFRN) and followed the established norms. 


\subsection{Materials}

Glycine, glucose, galactose, arabinose, fucose, mannose, rhamnose, glucuronic acid and xylose gallic acid, 3,3',5,5'-tetramethylbenzidine, ethylenediaminetetraacetic acid, hexadecyltrimethylammonium bromide and 2,4,6-trinitrobenzene sulfonic acid were purchased from Sigma (St. Louis, MO, USA) and lyophilized. IL-1 and IL-6 were purchased from BD Pharmingen (San Diego, CA, USA). $\mathrm{D}_{2} \mathrm{O}$, Folin Ciocalteau and $\mathrm{KBr}$ were purchased from Sigma (St. Louis, MO, USA).

\subsection{Polysaccharide Extraction and Fractionation}

The attainment of polysaccharides from $C$. montagnei was performed by modifications to the methodology proposed [10]. To obtain the polysaccharides from the fruiting bodies of the mushrooms, they were washed and dried at $40{ }^{\circ} \mathrm{C}$ and then were sprayed. For the extraction of the polysaccharides, $50 \mathrm{~g}$ of the tissue of the mushroom were used. To this powder was added 2 volumes of $80 \%$ acetone, leaving the mixture at $25{ }^{\circ} \mathrm{C}$ for $24 \mathrm{~h}$ and then filtering it. This was followed by extraction with chloroform-methanol $(2: 1, v / v)$ for $2 \mathrm{~h}$ at $60{ }^{\circ} \mathrm{C}$ under reflux and then filtering it. The supernatant was discarded, and to the precipitate was added $500 \mathrm{~mL}$ of distilled water, and it remained in the mixing bath at $100{ }^{\circ} \mathrm{C}$ for $3 \mathrm{~h}$. The supernatant was treated with ethanol $(3: 1, v / v)$, resulting in a precipitate that was separated from the supernatant by centrifugation $\left(4000 \times g\right.$ for $20 \min$ at $\left.25{ }^{\circ} \mathrm{C}\right)$. Next, the obtained precipitate was dried and pulverized.

\subsection{Chemical Analysis}

Total sugars were determined using phenol/sulfuric acid, as previously described, employing L-glucose as the standard, with readings taken at $490 \mathrm{~nm}$ [58]. The protein content was determined with the Coomassie blue reagent with readings taken at $595 \mathrm{~nm}$ [59]. The concentration of total phenolics was determined colorimetrically according to the standard procedure of Folin-Ciocalteu [60], and the readings were taken at $755 \mathrm{~nm}$. Aqueous solutions of gallic acid were used for the calibration curve. The total phenols, sugars and proteins were determined by interpolating the absorbance of the sample against the corresponding calibration curve.

\subsection{Infrared Analysis}

Infrared spectroscopy was performed on a 65 FT-IR PERKIN ELMER 104 spectrometer (PerkinElmer Inc., Wellesley, MA, USA), from 4000 to $400 \mathrm{~cm}^{-1}$. The polysaccharide was examined after drying under the form of a KBr wafer.

\subsection{Nuclear Magnetic Resonance (NMR)}

NMR analyses were performed at Universidade Federal do Paraná (UFPR) in a Bruker magneto model DRX 400 AVANCE series (Bruker BioSpin GmbH, Rheinstetten, Germany), in a pipe (wide-bore probe) of a 5-mm external diameter. The spectra were obtained at $80{ }^{\circ} \mathrm{C}$ using $10 \mathrm{mg}$ of polysaccharides dissolved in $0.5 \mathrm{~mL}$ of deuterated water $\left(\mathrm{D}_{2} \mathrm{O}\right)(99.75 \%)$. 


\subsection{Anti-Inflammatory Activity in the Ulcerative Colitis Model Induced by 2,4,6-Trinitrobenzene} Sulfonic Acid (TNBS)

The experimental colitis is a well-established model of intestinal inflammation and was induced in male rats $(n=10)$ as previously described [61]. Animals were fasted for $24 \mathrm{~h}$ before the experiment with free access to $5 \%$ glucose solution and were anesthetized with intraperitoneal administration of ketamine $(80 \mathrm{mg} / \mathrm{kg})$ and xylazine $(10 \mathrm{mg} / \mathrm{kg})$. The induction of colitis was conducted by intracolonic administration of $30 \mathrm{mg}$ of 2,4,6-trinitrobenzene sulfonic acid (TNBS) after being lyophilized, in $0.25 \mathrm{~mL}$ of $40 \%$ ethanol $(v / v)$ via a polyethylene catheter inserted into the lumen of the colon. This same procedure was carried out in a negative control group. However, control animals received $0.25 \mathrm{~mL}$ saline $(0.9 \%)$.

\subsection{Treatment of Colitis with Polysaccharides}

The rats were divided into two experimental groups: (1) the control group rats, both negative and positive, received only saline treatment; (2) all other mice in the other groups were treated with different doses of polysaccharides $(25,50$ and $75 \mathrm{mg} / \mathrm{kg})$ dissolved in saline. Treatments were administered intraperitoneally $24 \mathrm{~h}$ after induction of experimental colitis and were performed in two ways: from 12 to $12 \mathrm{~h}$ or 24 to $24 \mathrm{~h}$, both for $60 \mathrm{~h}$. Then, $12 \mathrm{~h}$ after the last treatment, the animals were euthanized, and the abdominal cavity was quickly opened, the colon removed, fragmented into similar sizes and opened for examination of macroscopic damage. Subsequently, sections were distributed for analysis.

\subsection{Macroscopic Analysis}

For the microscopic analysis, the animals were evaluated for intestinal damage by assigning a score using previously described a scale [62].

Score 0: No injuries.

Score 1: Hyperemia without ulceration.

Score 2: Linear ulceration without inflammation.

Score 3: Linear ulceration with inflammation.

Score 4: Two or more ulcerations and inflammation.

Score 5: Two or more ulcerations and inflammation or ulceration longer than $1 \mathrm{~cm}$ along the colon.

Score 6-10: If the lesions are greater than $2 \mathrm{~cm}$ in length longitudinally, 1 point for every extra inch will be awarded.

\subsection{Assessment of Myeloperoxidase Activity}

To evaluate the activity of MPO, colon samples from different groups were collected and frozen at $-20{ }^{\circ} \mathrm{C}$ until use. After thawing, the samples were weighed and homogenized in $50 \mathrm{mM}$ phosphate buffered saline (PBS), $\mathrm{pH} 7.4$. The homogenates were centrifuged at $8000 \mathrm{rpm}$ for $20 \mathrm{~min}$ at $4{ }^{\circ} \mathrm{C}$. The pellets were resuspended in $50 \mathrm{mM}$ PBS, pH 6.0, containing $0.5 \%$ hexadecyltrimethylammonium bromide (HETAB) and $10 \mathrm{M}$ ethylenediaminetetraacetic acid (EDTA). The resulting homogenates were subjected to cycles of freezing/thawing and sonicated. To the homogenized sample $(0.5 \mu \mathrm{L})$ 
was added $0.5 \mathrm{~mL}$ of solution containing $80 \mathrm{mM}$ PBS, $\mathrm{pH} 5.4,0.5 \%$ HETAB and $1.6 \mathrm{mM}$ 3,3',5,5'-tetramethylbenzidine (TMB). The mixture was incubated at $37{ }^{\circ} \mathrm{C}$, and the reaction was initiated by the addition of $0.3 \mathrm{mM}$ hydrogen peroxide. The readings will be held at $655 \mathrm{~nm}$. One unit of MPO activity was defined as the amount of enzyme present that will produce a change in absorbance of $1.0 \mathrm{U} / \mathrm{min}$ at $37^{\circ} \mathrm{C}$ in a final volume reaction containing the acetate. The results were quantified as $\mathrm{mU} / \mathrm{g}$ of sample [63].

\subsection{Evaluation of Alkaline Phosphatase Activity}

In this model, alkaline phosphatase acts as the catalyst for the hydrolysis of nitrophenylphosphate sodium $(5.5 \mathrm{mM})$ in glycine buffer $(50 \mathrm{mM}, \mathrm{pH}=10.5)$, which incorporates $\mathrm{MgCl}_{2}$ and forms a $p$-nitrophenol molecule, which presents a maximum absorption of $405 \mathrm{~nm}$. The results were expressed as $\mathrm{mU} / \mathrm{mg}$ of protein [64].

\subsection{Nitric Oxide}

The nitrite-nitrate concentration was measured using the Griess reaction and the addition of $100 \mu \mathrm{L}$ samples of colon homogenized in $50 \mathrm{mM}$ phosphate buffer, $\mathrm{pH} \mathrm{7,} \mathrm{obtained} \mathrm{in} \mathrm{item} \mathrm{2.8.} \mathrm{Absorbance} \mathrm{at}$ $540 \mathrm{~nm}$ was measured using the ELISA reader.

\subsection{Evaluation of Catalase Activity}

Colon samples from different groups were used to verify the activity of catalase (CAT). Samples of colon were homogenized in $50 \mathrm{mM}$ phosphate buffer, $\mathrm{pH} 7$. In a cuvette, $2950 \mu \mathrm{L}$ of the reaction solution (potassium phosphate buffer $50 \mathrm{mM}, \mathrm{pH} 7$, and $20 \mathrm{mM}$ hydrogen peroxide, $30{ }^{\circ} \mathrm{C}$ ) was added to $50 \mu \mathrm{L}$ of the diluted sample. The absorbance was measured at a wavelength of $240 \mathrm{~nm}$ for $5 \min [65]$.

\subsection{Analysis of Cytokines}

Colon samples from the different groups were weighed and homogenized in $0.3 \mathrm{~mL}$ of the solution of phosphate buffered saline (PBS, pH 7.2) at $4{ }^{\circ} \mathrm{C}$. Then, they were centrifuged at $4000 \mathrm{rpm}$ for $5 \mathrm{~min}$. The levels of IL-1 and IL-6 were determined using specific ELISA kits (enzyme immunosorbent assay), according to the manufacturer's recommendations.

\subsection{Histological Analyses}

Colon samples from all groups were removed, fixed in formalin, embedded in paraffin and sectioned. The sections were flushed in hematoxylin and eosin.

\subsection{Statistical Analyses}

Values are presented as the mean \pm standard deviation. Statistical analyses were done using Graphpad Prism. Analyses of variance (ANOVA) and Tukey-Kramer were used, considering $p<0.05$ as statistically significant. 


\section{Conclusions}

Extracts rich in glucans from the Caripia montagnei mushroom were used to evaluate their anti-inflammatory potential, well described in a model of colitis induced by TNBS. After the induction of colitis, the presence of colonic lesions, such as hyperemia and ulcerations, was observed. The results suggest that the increase in catalase activity by the polysaccharides of $C$. montagnei presents a protective effect in this model. Furthermore, their anti-inflammatory effect would be due to the decreased activity of myeloperoxidase and alkaline phosphatase, as well as the reduction of nitric oxide and IL-6, important inflammatory mediators of the inflamed colonic tissue, once again featured in the immunomodulating effects of this polysaccharide. Whether the anti-inflammatory action of C. montagnei in this model of colonic inflammation takes place exclusively by inhibition of inflammatory mediators, such as cytokines or NO, or by inhibition of the expression of NF- $\mathrm{B}$, still requires further investigation.

\section{Acknowledgments}

The authors would like to thank Diego Araujo Sabry and Guilherme Lanzi Sassaki (UFPR) for contributing to the analysis of NMR and the Brazilian National Council for Scientific and Technological Development (CNPq) and the Coordination and Improvement of Higher Education Personnel (CAPES) for the financial support.

\section{Conflicts of Interest}

The authors declare no conflict of interest.

\section{References}

1. Hendrickson, B.A.; Gokhale, R.; Cho, J.H. Clinical aspects and pathophysiology of inflammatory bowel disease.Clin. Microbiol. Rev. 2002, 15, 79-85.

2. Magalhães, A.F.N. Crohn's disease (CH). In Clinical Gastroenterology, 3rd ed.; Dani, R., Castro, L.P., Eds; Guanabara Koogan: Rio de Janeiro, Brazil, 1993; Volume 2, pp. 765-776.

3. Danese, S.; Fiocchi, C. Etiopathogenesis of inflammatory bowel diseases. World J. Gastroenterol. 2006, 12, 4807-4812.

4. Singleton, J.W. Progressin inflammatory bowel disease. Chin. J. Dig. Dis. 2005, 6, 59-61.

5. Head, K.A.; Jurenka, J.S. Inflammatory bowel disease. Part 1: Ulcerative colitis pathophysiology and conventional and alternative treatment options. Altern. Med. Rev. 2003, 8, 247-283.

6. Ardizzone, S.; Bianchi-Porro, G. Biologic therapy for inflammatory bowel disease. Drugs 2005, 65, 2253-2286.

7. Waldner, M.J.; Neurath, M.F. Novel cytokine-targeted therapies and intestinal inflammation. Curr. Opin. Pharmacol. 2009, 9, 702-707.

8. Gautam, R.; Jachak, S. Recent developments in anti-inflammatory natural products. Med. Res. Rev. 2009, 29, 767-820. 
9. Ruthes, A.C.; Carbonero, E.R.; Córdova, M.M.; Baggio, C.H.; Santos, A.R.S.; Sassaki, G.L.; Cipriani, C.R.; Gorin, P.A.J.; Iacomini, M. Lactariusrufus $(1 \rightarrow 3),(1 \rightarrow 6)-\beta$-D-glucans: Structure, antinociceptive and anti-inflammatory effects. Carbohydr. Polym. 2013, 94, 129-136.

10. Queiroz, L.S.; Nascimento, M.S.; Cruz, A.K.M.; Castro, A.J.G.; Moura, M.F.V.; Baseia, I.G.; Araujo, R.M.; Benevides, N.M.; Lima, L.F.; Leite, E.L. Glucans from the mushroom Caripia montagnei present anti-inflammatory activity. Int. Immunopharmacol. 2010, 10, 34-42.

11. Dore, C.M.P.G.; Azevedo, T.C.G.; Souza, M.C.R.; Rego, L.A.; Dantas, J.C.M.; Silva, F.R.F.; Rocha, H.A.O.; Baseia, I.G.; Leite, E.L. Anti-inflammatory, antioxidant and cytotoxic actions of $\beta$-glucan-rich extract from Geastrum saccatum mushroom. Int. Immunopharmacol. 2007, 7, 1160-1169.

12. Finimundy, T.C.; Gambato, G.; Fontana, R.; Camassola, M.; Salvador, M.; Moura, S.; Hess, J.; Henriques, J.A.P.; Dillon, A.J.P.; Roesch-Ely, M. Aqueous extracts of Lentinulaedodes and Pleurotussajor-caju exhibit high antioxidant capability and promising in vitro antitumor activity. Nutr. Res. 2013, 33, 76-84.

13. Kozarski, M.; Klaus, A.; Niksic, M.; Jakovljevic, D.; Helsper, J.P.F.G.; van Griensven, L.J.L.D. Antioxidative and immunomodulating activities of polysaccharide extracts of the medicinal mushrooms Agaricus bisporus, Agaricus brasiliensis, Ganoderma lucidum and Phellinus linteus. Food Chem. 2011, 129, 1667-1675.

14. Bellini, M.F.; Angel, J.P.; Matuo, R.; Terezan, A.P.; Ribeiro, L.R.; Mantovani, M.S. Antigenotoxicity of Agaricus blazei mushroom organic and aqueous extracts in chromosomal aberration and cytokinesis block micronucleus assays in CHO-k1 and HTC cells. Toxicol. in Vitro 2006, 20, 355-360.

15. Paglia, D.E.; Valentine, W.N. Studies on the quantitative and qualitative characterization of erythrocyte glutathione peroxidase. J. Lab. Clin. Med. 1967, 70, 158-169.

16. Worthington, D.J.; Rosemeyer, M.A. Human glutathione reductase: Purification of the crystalline enzyme from erythrocytes. Eur. J. Biochem. 1974, 48, 167-177.

17. Mathlouthi, M.; Koenig, J.L. Vibrational spectra of carbohydrates. Adv. Carbohydr. Chem. Biochem. 1986, 44, 87-89.

18. Stone, B.A.; Clarke, A.E. Chemistry and Biology of (1,3)- $\beta$-Glucans; La Trobe University Press: Boondora, Australia, 1992; p. 808.

19. Fang, J.; Wang, Y.; Lv, X.; Shen, X.; Ni, X.; Ding, K. Structure of the $\beta$-glucan from

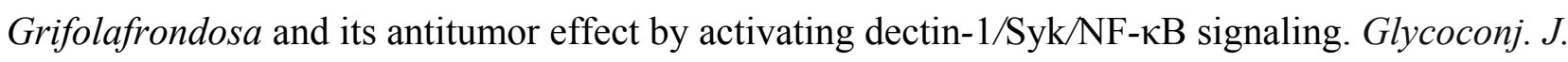
2012, 29, 365-377.

20. Roy, S.K.; Das, D.; Mondal, S.; Maiti, D.; Bhunia, B.; Maiti, T.; Islam, S.S. Structural studies of an immunoenhancing water-soluble glucan isolated from hot water extract of an edible mushroom, Pleurotus florida, cultivar Assam Florida. Carbohydr. Res. 2009, 344, 2596-2601.

21. Perlin, A.S.; Casu, B. Carbon-13 and proton magnetic resonance spectra of $\mathrm{D}^{13} \mathrm{C}-$ glucose. Tetrahedron Lett. 1969, 34, 2919-2924.

22. Ghosh, K.; Chandra, K.; Ojha, A.K.; Islam, S.S. NMR and MALDI-TOF analysis of the water-soluble glucan from an edible mushroom, Volvarielladiplasia. Carbohydr. Res. 2008, 343, 2834-2840. 
23. Huang, Z.P.; Zhang, L.N. Chemical structures of water-soluble polysaccharides from Rhizoma Panacis Japonici. Carbohydr. Res. 2009, 344, 1136-1140.

24. Sadovskaya, I.; Evgeny, V.; Jianjun, L.; Abderrahman, H.; Kowalska, K.; Filloux, A. High-level antibiotic resistance in Pseudomonas aeruginosa biofilm: The ndvB gene is Involved in the production of highly phosphorylated glycerol-beta-(1->3)-glucans, which bind aminoglycosides. Glycobiology 2010, 20, 895-904.

25. Hoffmann, J.C.; Pawlowski, N.N.; Kuhl, A.A.; Hohne, W.; Zeitz, M. Animal models of inflammatory bowel disease: an overview. Pathobiology 2002, 70, 121-130.

26. Carlson, M.; Raab, Y.; Seveus, L.; Xu, S.; Hallgren, R.; Venge, P. Human neutrophil lipocalin is a unique marker of neutrophil inflammation in ulcerative colitis and proctitis. Gut 2002, 50, 501-506.

27. Talero, E.; Sánchez-Fidalgo, S.; de la Lastra, C.A.; llanes, M.; Calvo, J.R.; Motilva, V. Acute and chronic responses associated with adrenomedullin administration in experimental colitis. Peptides 2008, 29, 2001-2012.

28. Martín, A.R.; Villegas, I.; Sánchez-Hidalgo, M.; de la Lastra, C.A. The effects of resveratrol, a phytoalexin derived from red wines, on chronic inflammation induced in an experimentally induced colitis model. Br. J. Pharmacol. 2006, 147, 873-885.

29. Sanchez de Medina, F.; Martinez-Augustin, O.; Gonzalez, R.; Ballester, I.; Nieto, A.; Galvez J.; Zarzuelo, A. Induction of alkaline phosphatase in the inflamed intestine: A novel pharmacological target for inflammatory bowel disease. Biochem. Pharmacol. 2004, 68, 2317-2326.

30. Pavlick, K.P.; Laroux, F.S.; Fuseler, J.; Wolf, R.E.; Gray, L.; Hoffman, J.; Grisham, M.B. Role of reactive metabolites of oxygen and nitrogen in inflammatory bowel disease. Free Radic. Biol. Med. 2002, 33, 311-332.

31. Buffinton, G.D.; Doe, W.F. Depleted mucosal antioxidant defences in inflammatory bowel disease. Free Radic. Biol. Med. 1995, 19, 911-918.

32. Abbas,A.K.; Janeway, C.A.J.R. Immunology: Improving on nature in the twenty-first century. Cell 2000, 100, 129-138.

33. Gordon, S. Macrophage Function Disorders. In Encyclopedia of Life Sciences; John Wiley \& Sons, Ltd.: Chichester, UK, 2001; Volume 1, pp. 1-11.

34. Hermann, G.E.; Rogers, R.C.; Bresnahan, J.C.; Beattie, M.S. Tumor necrosis factor-alpha induces cfos and strongly potentiates glutamate-mediated cell death in the rat spinal cord. Neurobiol. Dis. 2001, 8, 590-599.

35. Chang, A.Y.W.; Chan, J.Y.H.; Chan, S.H.H. Differential distribution of nitric oxide synthase isoforms in the rostral ventrolateral medulla of the rat. J. Biomed. Sci. 2003, 10, 285-291.

36. Koutroubakis, I.E.; Malliaraki, N.; Dimoulios, P.D.; Karmiris, K.; Castanas, E.; Kouroumalis, E.A. Decreased total and corrected antioxidant capacity in patients with inflammatory bowel disease. Dig. Dis. Sci. 2004, 49, 1433-1437.

37. Bouzid, D.; Gargouri, B.; Mansour, R.B.; Amouri, A.; Tahri, N.; Lassoued, S.; Masmoudi, H. Oxidative stress markers in intestinal mucosa of Tunisian inflammatory bowel disease patients. Saudi J. Gastroenterol. 2013, 19, 131-135.

38. Lull, C.; Wichers, H.J.; Savelkoul, H.F.J. Antiinflammatory and immunomodulating properties of fungal metabolites. Mediat. Inflamm. 2005, 2, 63-80. 
39. Stallmach, A.; Hagel, S.; Bruns, T. Adverse effects of biologics used for treating IBD. Best Pract. Res. Clin. Gastroenterol. 2010, 24, 167-182.

40. Krawisz, J.E.; Sharon, P.; Stenson, W.F. Quantitative assay for acute intestinal inflammation based on myeloperoxidase activity. Gastroenterology 1984, 87, 1344-1350.

41. Roupas, P.; Keogh, J.; Noakes, M.; Margetts, C.; Taylor, P. The role of edible mushrooms in health: Evaluation of the evidence. J. Funct. Foods 2012, 4, 687-709.

42. Palacios, I.; Lozano, M.; Moro, C.; D’Arrigo, M.; Rostagno, M.A.; Martínez, J.A.; García-Lafuente, A.; Guillamón, E.; Villares, A. Antioxidant properties of phenolic compounds occurring in edible mushrooms. Food Chem. 2011, 3, 674-678.

43. Dudhgaonkar, S.; Thyagarajan, A.; Sliva, D. Suppression of the inflammatory response by triterpenes isolated from the mushroom Ganoderma lucidum. Int. Immunopharmacol. 2009, 11, 1272-1280.

44. Fangkrathok, N.; Junlatat, J.; Sripanidkulchai, B. In vivo and in vitro anti-inflammatory activity of Lentinuspolychrous extract. J. Ethnopharmacol. 2013, 3, 631-637.

45. Lavi, I.; Friesem, D.; Geresh, S.; Hadar, Y.; Schwartz, B. An aqueous polysaccharide extract from the edible mushroomPleurotusostreatus induces anti-proliferative and pro-apoptotic effects on HT-29 colon cancer cells. Cancer Lett. 2006, 244, 61-70.

46. Suseem, S.R.; Mary, S.A.; Neelakanda, R.P.; Gregory, M. Evaluation of the analgesic activity of ethyl acetate, methanol and aqueous extracts of Pleurotuseous mushroom. Asian Pac. J. Trop. Med. 2011, 2, 117-120.

47. Nascimento, M.S.; Magalhães, J.E.M.; Pinheiro, T.S.; Silva, T.A.; Coutinho, L.G.; Baseia, I.G.; Lima, L.F.A.; Leite, E.L. Polysaccharides from the fungus Scleroderma nitidum with anti-inflammatory potential modulate cytokine levels and the expression of nuclear factor $\kappa \mathrm{B}$. Rev. Bras. Farmacogn. 2012, 22, 60-68.

48. Battle, J.; Ha, T.; Li, C.; Della Beffa, V.; Rice, P.; Kalbfleisch, J.; Browder, W.; Williams, D. Ligand binding to the $(1 \rightarrow 3)-\beta$-D-glucan receptor stimulates NFkappaB activation, but not apoptosis in U937 cells. Biochem. Biophys. Commun. 1998, 249, 499-504.

49. Yoon, W.J.; Ham, Y.M.; Kim, S.S.; Yoo, B.S.; Moon, J.Y.; Baik, J.S.; Lee, N.H.; Hyun, C.-G. Suppression of pro-inflammatory cytokines, iNOS, and COX-2 expression bybrown algae Sargassum micracanthumin RAW 264.7 macrophages. EurAsian J. BioSci. 2009, 3, 130-143.

50. Gordon, S. Alternative Activation of Macrophages. Nat. Rev. Immunol. 2003, 3, 23-35.

51. Mitsuyama, K.; Sata, M.; Rose-John, S. Interleukin-6 trans-signaling in inflammatory bowel disease. Cytokine Growth Factor Rev. 2006, 17, 451-461.

52. Gloire, G.; Legrand-Poels, S.; Piette, J. NF- $\kappa$ B activation by reactive oxygen species: Fifteen years later. Biochem. Pharmacol. 2006, 72, 1493-1505.

53. Aupperle, K.R.; Bennett, B.L.; Boyle, D.L.; Tak, P.P.; Manning, A.M.; Firestein, G.S. NF-кB regulation by IkB kinase in primary fibroblast-like synoviocytes. J. Immunol. 1999, 163, 427-433.

54. Molavi, B.; Mehta, J.L. Oxidative stress in cardiovascular disease: molecular basis of its deleterious effects, its detection, and therapeutic considerations. Curr. Opin. Cardiol. 2004, 19, 488-493.

55. Jayasooriya, R.G.P.T.; Kang, C.; Seo, M.; Choi, Y.H.; Jeong, Y.; Kim, G. Exopolysaccharide of Laetiporus sulphureus var. miniatus downregulates LPS-induced production of $\mathrm{NO}, \mathrm{PGE}_{2}$, and 


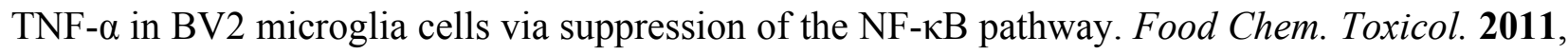
$49,2758-2764$.

56. Kim, H.G.; Yoon, D.H.; Lee, W.H.; Han, S.K.; Shrestha, B.; Kim, C.H.; Lim, M.H.; Chang, W.; Lim, S.; Choi, S.; et al. Phellinus linteus inhibits inflammatory mediators by suppressing redox-based NF-kB and MAPKs activation in lipopolysaccharide-induced RAW 264.7 macrophage. J. Ethnopharmacol. 2007, 114, 307-315.

57. Van, Q.; Nayak, B.N.; Reimer, M.; Jones, P.J.H.R.; Fulcher, G.; Rempel, C.B. Anti-inflammatory effect of Inonotus obliquus, Polygala senega L., and Viburnum trilobum in acell screening assay. J. Ethnopharmacol. 2009, 125, 487-493.

58. Dubois, M.; Gilles, K.A.; Hamilton, J.K.; Rebers, P.A.; Simth, F. Colorimetric method for the determination of sugars, and related substances. Anal. Chem. 1956, 28, 350-356.

59. Bradford, M.M. A rapid and sensitive method for the quantization of microgram quanties of protein utilizing the principle of protein-dye binding. Anal. Biochem. 1976, 7, 248-254.

60. Singleton, V.L.; Rossi, J.A. Colorimetry of total phenolics with phosphomolybdic-phosphotungstic acid reagents. Am. J. Enol. Viticult. 1965, 20, 144-158.

61. Liu, L.; Guo, Z.J.; Lv, Z.G.; Sun, Y.; Cao, W.; Zhang, R.; Liu, Z.; Li, C.; Cao, S.; Mei, Q. The beneficial effect of polysaccharide on Rheum tanguticum protecting against diarrhea, colonic inflammation and ulceration in rats with TNBS-induced colitis: The Role of macrophage mannose receptor in inflammation and immune response. Int. Immunopharmacol. 2008, 8, 1481-1492.

62. Rodriguez-Cabezas, M.E.; Gálvez, J.; Lorente, M.D.; Concha, A.; Camuesco, D.; Azzouz, S.; Osuna, A.; Redondo, L.; Zarzuelo, A. Dietary fiber down-regulates colonic tumor necrosis factor alpha and nitric oxide production in trinitrobenzenesulforic acid induced colitic rats. J. Nutr. 2002, 132, 3263-3271.

63. Grisham, M.B.; Beniot, J.N.; Granger, D.N. Assessment of leukocyte involvement during ischemia and reperfusion of intestine. Methods Enzymol. 1990, 186, 729-742.

64. Smith, P.K.; Krohn, R.I.; Hermanson, G.T.; Mallia, A.K.; Gartner, F.H.; Provenzano, M.D.; Fujimoto, E.K.; Goeke, N.M.; Olson, B.J.; Klenk, D.C. Measurement of protein using bicinchoninic acid. Anal. Biochem. 1985, 150, 76-85.

65. Havir, E.A.; McHale, N.A. Biochemical and developmental characterization of multiple forms of catalase in tobacco leaves. Plant Physiol. 1987, 84, 450-455.

(C) 2014 by the authors; licensee MDPI, Basel, Switzerland. This article is an open access article distributed under the terms and conditions of the Creative Commons Attribution license (http://creativecommons.org/licenses/by/3.0/). 